\title{
VIDENSKABSMANDEN OG BRYGGEREN
}

\author{
EMIL CHR. HANSEN OG J. C. JACOBSEN
}

AF

\author{
Kristof GlamanN
}

I

$\mathrm{S}$ amspillet mellem forskning og erhvervsliv er en aktuel relation, som er på manges læber, teoretikeres og praktikeres. På macroplanet synes ingen regering uanset partifarve at være i tvivl om den forskningsmæssige og teknologiske infrastrukturs betydning for nationalprodukt, konkurrenceevne og lignende vitale størrelser i samfundet. På microplanet lyder parolen, at virksomheder over en vis størrelse må satse en del af deres investeringsbudgetter på produktudvikling og forskning til sikring af fremtiden. Vanskeligere er det at måle og kvantificere sammenhængen. Adskillige imponderabilia gemmer sig ved nærmere eftersyn i problemkomplekset, forhold som gør, at såkaldte case studies trods den dem iboende begrænsning - må have interesse. I det følgende skal jeg forsøge at bidrage med et sådant fra industriforskningens barndom.

Branchen er bryggeriindustrien. Jeg har valgt en periode, som er bemærkelsesværdig ved sine meget korte, ja ekstraordinært korte forbindelseslinier mellem teorien og dennes praktiske anvendelse og derfor meget anskuelig. Det drejer sig om de henved fem og tyve år fra midten af I 860'erne til slutningen af r880'erne. Jeg har foretrukket den biografiske indfaldsvinkel, ikke blot fordi man ved at følge aktørerne på nærmere hold kan iklæde fremstillingen kød og blod, men også fordi denne vinkel belyser forhold, som for hovedpartens vedkommende slipper igennem de kvantitative analysers stormaskede net, eksempelvis spørgsmål som forholdet mellem forsker og industriforetager, informationsspredning, royalty og arbejdsvilkår. Endelig rummer emnet inter- 
essante bidrag til videnskabshistorien. På en meget konkret măde er nogle af kemiens, biologiens og fysiologiens gennembrud i det 19 . århundrede knyttet til gæringsindustrierne. Om man vil, kan man gerne kalde dem for paradigmatiske. Nye discipliner - i samtiden sammenfattet under betegnelsen „zymoteknikken“ - fremstår i denne periode. Tonen i faglitteraturen er pionerens, ofte polemisk, man kæmper om trofæerne. Vore dages bryggeri-, sprit- og vinfabrikation hviler på et fundament, som støbes i disse årtier. Også sterilisationsteknikken grundlægges her, og på den bygger det 20. århundredes konservesindustri. En af vores dages største vækstindustrier, medicinal- og enzymindustrien, står i gæld til forskere som Robert Koch i Berlin, Louis Pasteur i Paris og Emil Chr. Hansen i København; eksempelvis nåede en af Hansens grundlæggende metoder, det såkaldte rekonstruktionsforsøg, i I940'erne mere almen udbredelse som et vigtigt værktøj i den genetiske analyse af mikroorganismer.

Først et par ord om den europæiske bryggeriindustri.') For godt og vel hundrede år siden befandt de europæiske bryggerier sig i en overgangsfase, ud af hvilken den moderne industri fremstod. Stordrift havde ganske vist eksisteret $\mathrm{i}$ England siden det $\mathrm{I} 8$. århundrede, men også her indtraf $i$ løbet af $r$ 880'erne afgørende ændringer, især i markedsforholdene, som fremmede latente koncentrationstendenser blandt bryggerierne og førte dem ind $\mathrm{i}$ en ny fase. På det europæiske kontinent var traditionelle markeder i hastigt opbrud. Doktrinerne om økonomisk liberalisme og frihandel fik i løbet af 1860 'erne og 1870 'erne tilslutning fra flere og flere lande. Hvor bryggere tidligere havde været bundet af det lokale markeds snæverhed, bl.a. som følge af produktets begrænsede holdbarhed, og været henvist til at lade deres foretagsomhed udfolde sig på tilgrænsende ikke-bryggerimæssige områder, blev nu selve bryggeriet en tumleplads for deres opfindsomhed og for kræfternes frie spil. Det mere holdbare, undergærede, såkaldte lagerøl, hvortil også pilsnerøllet henhører, kom i offensiven og trængte de gammeldags overgærede øltyper - blandt hvilke hvidtøllet - tilbage. Selv om det nationale marked ubetinget var det bærende grundlag for så at sige alle tidens førende bryggerier, spillede forestillingen om øl som eksportartikel en vigtig rolle ved etableringen af mange nye virksomheder.

Teknologisk banedes vejen for fremstilling af øl i hidtil ukendt skala. Dampkogning, som forsøgsvis indførtes omkring midten af århundredet men mødtes med skepsis, vandt i forbedrede versioner indpas i løbet af 
I 860'erne og I87o'erne. På bryggerikongressen i Wien I873 præsenteredes eliten af Europas bryggere for tre forskellige typer kølekompressorer. Gabriel Sedelmayer d. y. valgte to år senere den af dr. Linde konstruerede kompressor til sit berømte bryggeri Zum Spaten i München, hvilket blev indledningen til Lindesystemets sejrsgang. 1876 lod Anton Dreher det indrette $\mathrm{i}$ sit bryggeri $\mathrm{i}$ Wien (Schwechat), 1878 opstilledes en Linde-maskine hos J. C. Jacobsen på Carlsberg i København, I88o hos Heineken i Rotterdam, hvor endnu en repræsentant for den moderne europæiske bryggeriindustris foregangsmænd, brygger W. Feltmann, var ansvarlig for introduktionen. Industriel aftapning af øllet på flasker, enten på bryggeriet eller på særlige tappeanstalter, var et tredie teknologisk område, som åbnede sig i denne periode og bidrog til en omvæltning $\mathrm{i}$ øllets distribution med en mere direkte markedsføring fra bryggeri til konsument som følge.

Stordriften betød bedre økonomi i udnyttelsen af bryggeriets materialer, men også mere kapitalintensive processer og anlæg. Nye partnere og interesser bragtes dermed ind $\mathrm{i}$ bryggerierne, som traditionelt overalt $\mathrm{i}$ Europa havde været en meget lukket og eksklusiv verden. Dette affødte igen nye ledelsesstrukturer.

\section{III}

Grundlæggende teoretiske landvindinger voksede i disse årtier ud af det praktiske livs problemer på en meget direkte måde. ${ }^{2}$ ) Louis Pasteur's virke er et glimrende eksempel herpå. Han blev det beundrede forbillede for mange, læg og lærd. Omkring århundredets midte havde Pasteur embede i Lille, det nordfranske centrum for fremstilling af eddike, vin, øl og brændevin. Her modtog han talrige henvendelser fra producenter om bedærvet vin og ol og blev dermed skubbet ind i gæringens mysterier. Senere fortsatte han sine studier herover i Paris ved Ecole normale supérieure, hvor han var blevet direktør, og sidenhen ved sin lærestol i kemi ved Sorbonne universitetet. I I 863 opfordrede kejser Napoleon III ham personligt til at udforske årsagerne til vinens sygdomme. Vinen og vinkulturen var en af de piller, hvorpå det gamle Frankrigs økonomi hvilede, og krisen i denne sektor kunne man med god ret kalde for national.

Resultatet forelå tre år senere med værket Études sur le vin. Pasteur's metode bestod i opvarmning af vin til mellem $60^{\circ} \mathrm{og} 70^{\circ} \mathrm{C}$ for derved at gøre produktet mere holdbart. Opvarmningsmetoden, „pasteuriseringen", stillede han efter at have taget patent derpå (æren er det fagreste træ i skoven) gratis til rådighed for enhver, der måtte ønske at benytte 
den. Den blev snart udvidet til at omfatte behandlingen af en række andre næringsmidler. Medens Pasteur gik stærkt ind for en varmebehandling af vin, var han tøvende med hensyn til en tilsvarende behandling af øl. Hans landsmand, brygger Eugène Velten, var imidlertid umiddelbart efter udsendelsen af Études sur le vin begyndt at varmebehandle sit $ø$ l efter Pasteur's metode, dog med anvendelse af lavere temperaturer end de af Pasteur til vins behandling anbefalede.

Efter det ydmygende nederlag $i$ den tysk-franske krig $1870-7 \mathrm{I}$ påbegyndte Louis Pasteur studier inden for selve bryggeriindustrien med det patriotiske mål for øje at gøre den franske bryggeriindustri mere konkurrencedygtig. Tysk øl havde vundet indpas i Frankrig, ikke mindst i Paris, hvor det var faldet i publikums smag. Fransk øl, derimod, tålte ikke eksport. 1876 offentliggjorde han sine studier herover i Études sur la bière.

I dette værk - som hurtigt blev bryggernes bibel (det er således ikke tilfældigt, at både J. C. og Carl Jacobsen lod sig afbilde med Pasteur's bog liggende foran på bordet) - påviste forfatteren meget overbevisende, at gæren, som dengang benyttedes til fremstilling af øl, vin, alkohol og brød, indeholdt forureninger i form af eddike- og mælkebakterier, forskellige mug- og skimmelsvampe, den grønne penicillium og diverse vildgærarter. Pasteur anviste en rensningsprocedure, som begunstigede væksten af den ønskede gær. Behandlingen af en kultur med vinsyre og alkohol reducerer bakteriefloraen, som foretrækker basiske betingelser. Tillige opdagede han, at overgær bliver drabt $\mathrm{i}$ en sådan vinsyreopløsning ved $50^{\circ} \mathrm{C}$, og at dette kan bruges til at bestemme, om en kultur af overgær er ren eller ej.

Trods anvendelsen af Pasteur's „rene“ gær kom bryggerierne mange steder dog stadigvæk ud for slemme overraskelser. Tøvende måtte man erkende, at vinsyre-metoden ikke var ufejlbarlig. Var et bryg først slået fejl, hjalp det intet at pasteurisere ollet efter aftapningen. De ramte bryggerier måtte standse driften og søge dilemmaet løst ad traditionel empirisk vej; det vil sige, at man omhyggeligt rensede alle gærkar og alt, hvad øllet ellers kom i berøring med, hvorpå man rekvirerede frisk gær til påsæt fra et ikke-inficeret bryggeri og håbede på bedre held i næste omgang.

Først gennem en helt ny erkendelse af alkoholsvampenes fysiologi og morfologi lykkedes det for alvor at trænge ind i og kortlægge gærkulturerne og i forbindelse dermed at anvise en metode, som betød væsentlige forbedringer af hele gæringsteknologien, og som omsider effektivt kurerede „ølsygen“. Denne erkendelse skyldes den danske forsker Emil 
Chr. Hansen, der påviste, at gær ikke er et enhedsbegreb, men kan spaltes op i et flertal af arter, hvoraf kun få er anvendelige i bryggeriet. De til ølbrygning egnede arter kaldte han kulturgær, de andre vildgær. Allerede ved læsningen af Études sur la bière, som Hansen fik til anmeldelse, havde tvivlen meldt sig. I margenen ved afsnittet om den rene gær og vinsyremetoden noterede han: „Det er rimeligt, at spørgsmålet er meget mere kompliceret, og at der her ikke er tale om én, men om flere gærarter, som overlever den omtalte behandling. “3) Pasteur's rensningsprocedure kunne på kort sigt forbedre en gærkultur ved at bakterierne dræbtes, men den førte ikke til en absolut ren kultur af overgær, undergær eller vingær.

„Ideerne kommer som bekendt flyvende af sig selv," var Hansens facit senere hen i livet, ,når praktiske løsninger er mulige kan man sige, at ideerne ligger i luften; men udførelsen kommer ikke af sig selv. ${ }^{\text {"4 }}$ )

Som andre af det 19. århundredes store naturvidenskabsmænd var han en fremragende eksperimentator. De teknikker, han udviklede til adskillelse af gærarterne og opformering af kolonier, som består af afkom fra en enkelt celle - eller som man i dag siger: en klon - er klassiske. Hansen fremlagde dem for den videnskabelige verden i 1883 . De omfattede en såkaldt fluktuationsprøve, endvidere et rekonstruktionsforsøg og endelig en gelatinepladeteknik, som i forbindelse med et kulturkammer af egen konstruktion satte ham i stand til under mikroskop at følge udviklingen af en enkelt celle til en koloni. Gelatinesubstratteknikken havde Hansen lært under et besøg hos Robert Koch i Berlin efteråret $\mathrm{I} 882$, hvor den anvendtes ved bakteriekulturer. Kommet så vidt overførte han under sterile betingelser kolonien til en flaske med et egnet, flydende næringssubstrat og opnåede herved en kultur, fra hvilken opformeringen af rene gærlinier til anvendelse i bryggerierne kunne ske.

En række rene gærkulturer blev anlagt, deriblandt den verdensberømte Carlsberg undergær I, som viste sig altid at give øl med god smag, god lugt og høj stabilitet. En anden linie, Carlsberg undergær II, var også en anvendelig ølgær med hurtig nedgæring af urten. Den gav øllet en fyldigere smag end nr. I, men en længere holdbarhed af øllet kunne ikke opnås ved denne gærstamme. Den efter Pasteur opkaldte linie Saccharomyces pastorianus viste sig at være uegnet til ølbrygning. Såvel i renkultur som i blandinger med de to andre linier fremkaldte den en dårlig, bitter smag og en røglignende lugt ved øllet.

Fra det eksperimentelle stadium gik vejen hurtigt videre til det praktiske, som nåedes i 1885 . Sammen med Gamle Carlsbergs admini- 
strerende direktør, S. A. van der Aa Kühle, udformede Hansen et halvkontinuert gærpropageringsapparat, som blev sat i produktion hos kobbersmed W. E. Jensen, København. Apparatet gik sin sejrsgang jorden over og var $\mathrm{i}$ anvendelse $\mathrm{i}$ henved roo år.

Med Hansens teoretisk/praktiske indsats, hans reform, fjernedes en af de væsentligste hindringer, som i århundreder havde forhindret en kvalitetsstyring af ølpoduktionen, der nu kunne sættes op i større skala. Propageringsapparatet bød på et enkelt og let betjent system uden svigt.

Emil Chr. Hansen fortsatte iøvrigt sine studier over gærsvampene med andre banebrydende arbejder over gærens livscyklus i naturen og over dens taxonomi. I de seneste år af sit flittige forskerliv drev han et intenst forsøgsarbejde over den miljø- og arveligt betingede variation $\mathrm{i}$ renkulturer af gær. Især den genetiske og biokemiske baggrund for forskellen mellem overgær og undergær optog ham.

\section{IV}

Hansens arbejdsplads var Carlsberg Laboratoriets fysiologiske afdeling, et ungt laboratorium oprettet i 1876 af Carlsberg Bryggeriets grundlægger J. C. Jacobsen og indkorporeret som en afdeling af det samtidigt dermed oprettede Carlsbergfond, i hvis varetægt Jacobsen ønskede, at hans livsværk skulle bero efter hans død. ${ }^{5}$ )

Det var i det 19. århundrede ganske usædvanligt, at en foretager oprettede et egentligt forskningslaboratorium med den opgave at trænge ned til det erkendelsesmæssige grundlag for produktionsprocesserne.

Statutterne for Carlsbergfondet anførte, at laboratoriets opgave skulle være ved selvstændige undersøgelser at prøve de lærdomme, som videnskaben allerede havde tilvejebragt, og udvikle dem ved fortsatte studier til „et muligst fuldstændigt videnskabeligt grundlag for maltnings-, brygnings- og gærings-operationerne." Af aktuelle arbejdsopgaver opregnede statutterne bl.a. undersøgelser af det færdige produkt, øllet, dets egenskaber og betingelser for dets smag, holdbarhed og forædling, samt undersøgelser af grundene til de stundom indtrædende uregelmæssigheder i brygningsoperationerne og i det hele taget studier til forklaring af alle særegne fænomener. Det understregedes, at laboratoriets forskningsresultater skulle offentliggøres, også med tanke på dets udenlandske kontakter, at samkvemmet med udenlandske forskere skulle prioriteres højt, og at laboratoriet iøvrigt ikke måtte påtage sig at være praktisk bryggerskole for elever uden videnskabelige forkundskaber, endsige fungere som et attestudstedende analyselaboratorium. Det skulle heller ikke overflødiggøre det i forvejen etablerede driftslaborato- 


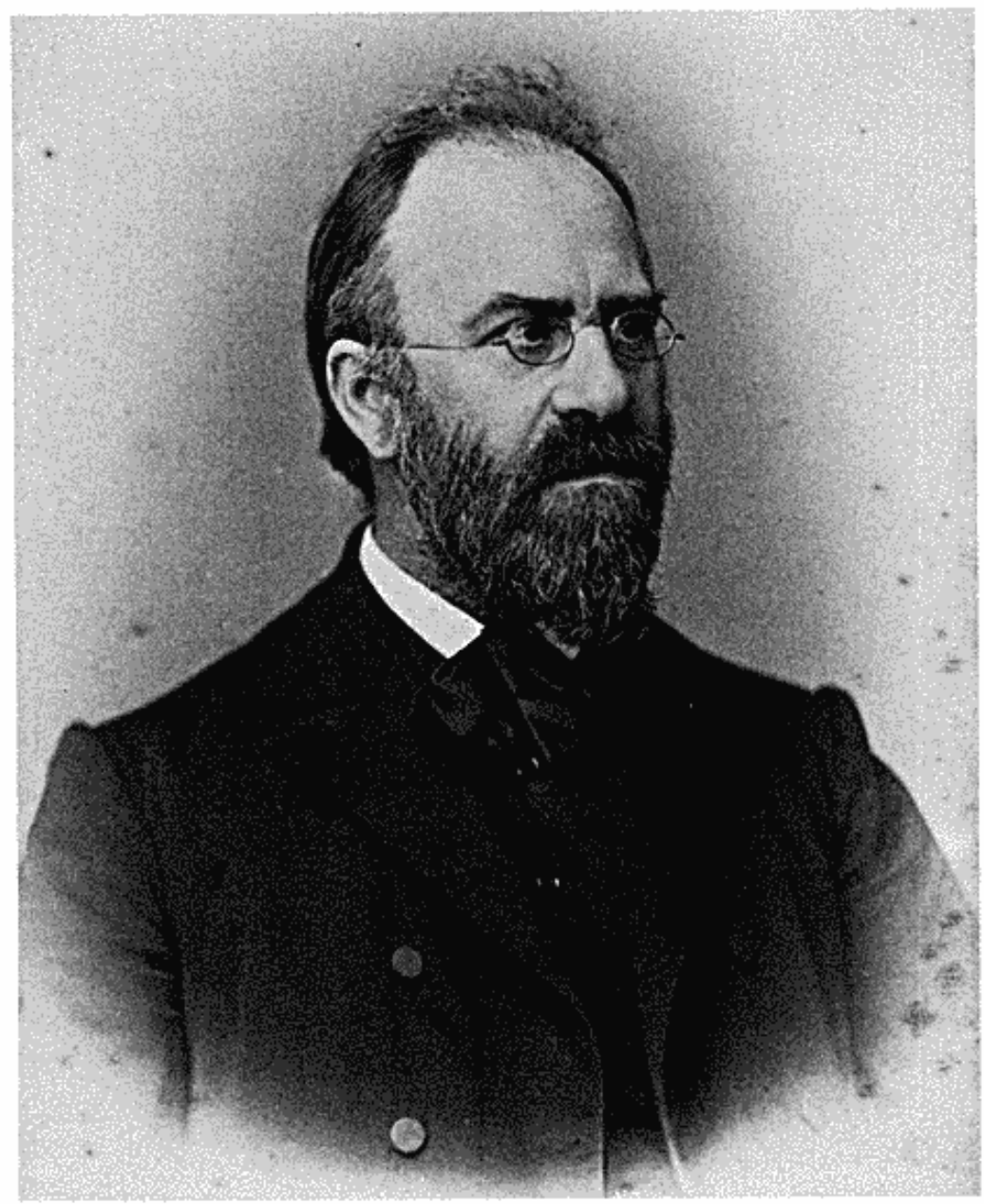

Emil Chr. Hansen, fotograferet i 1888 . Carlsberg Museum.

rium, som havde ansvaret for kontrollen med den løbende produktion.

Carlsberg Laboratoriet fik en flyvende start med en hurtigt opnået international placering. Hertil bidrog i høj grad også Hansens kollega, professor J. Kjeldahl, lederen af laboratoriets kemiske afdeling, hvis arbejder blev kendt verden over, bl.a. hans metode, ligeledes publiceret i I 883 , til bestemmelse af nitrogen i organiske stoffer. Forskningsfaciliteterne på laboratoriet var gode; da man i 1897 tog en helt ny laboratoriebygning i brug, blev de fremragende. Der var rigelige rejsemidler til rådighed, og gæster udefra blev snart et karakteristisk træk i laboratoriets hverdag.

Alligevel, går man tættere på begivenhederne og personerne i disse 
indholdsrige år, er ikke alt lutter idyl. Om man ved drama forstår modsætningernes ejendommelighed, rummer beretningen om gærens rendyrkning et dramatisk element, som ikke for har været fremdraget, men som fortjener at blive det, da det bidrager til at uddybe karakteristikken af de personligheder, der var hovedaktører i spillet: Emil Chr. Hansen og J. C. Jacobsen, videnskabsmanden og bryggeren, med den store Pasteur, le savant maître, i gæsterollen.

\section{V}

Emil Chr. Hansen tvivlede aldrig på sine gode evner, ej heller var han i tvivl om sit kald, som var videnskabsmandens. Kaldet var imidlertid svært at realisere. Virkelighedens verden var grum og hård. Egentlig kan man godt kalde Emil Chr. Hansen for et proletarbarn blandt det 19 . århundredes danske videnskabsmænd. Han kom fra forhold, de fleste af hans fagfæller næppe drømte om. ${ }^{6}$ )

Barndomshjemmet lå i Ribe. Navnlig i årene under og efter Treårskrigen kneb det for faderen, der var maler, at klare næringen og underholde familien, som efterhånden talte fem børn, hvoraf Emil var den ældste (født $184_{2}$ ). I stigende grad blev det moderen, som, efter at børnefødslernes tid var omme, holdt familien oven vande og borte fra den frygtede fattiggård. Medens faderen resignerede og drømte om store mænd og gerninger, eller syslede med aldrig realiserede projekter, sled madam Hansen i det som vaske- og kogekone. Hun var - med sønnens ord - af datidens seje vestjyske kvinderace, der havde tunger som rageknive og som tog hårdt på alt, både legemligt og åndeligt talt.

Stiftsbyen Ribe rummede store standsforskelle. I sine ikke-færdiggjorte erindringer taler Hansen om det uoverstigelige svælg, som fandtes mellem toppen, bestående af bisp, stiftsamtmand og storkøbmænd, og bunden, hvor maleren og hans familie befandt sig. Denne bevidsthed om klasseforskelle forlod ham aldrig. Som dreng havde han lånt H. C. Andersens Mit Livs Eventyr på lejebiblioteket og slugt den ved tællelyset omkring familiebordet. Som gammel måtte han erkende, at han ikke havde fået fynboens fromme og barnlige sind i vuggegave. De fornemme skulle ikke klappe eller kærtegne ham. "Når man ikke har dragt til at komme i det store selskab, skal man helst blive hjemme. Verden ser nu engang så meget på det ydre", var en af hans maximer. ${ }^{7}$ )

Henvist til at klare sig selv modnedes han tidligt til bevidstheden om eget værd. Men han var sårbar i sindet, følsom over for kritik og opretholdt livet igennem et stærkt beredskab mod omverdenen. At få ideerne var én ting, en anden at bevise dem og fă dem godtaget. Det 
krævede slid og kamp. Kamp er et centralt begreb i Hansens verden. Kampen for eksistensen, for en uddannelse og for anerkendelse.

Da der ikke var răd til latinskole, kom Emil i købmandslære, hvilket ikke huede ham; derpå uddannedes han i faderens håndværk, og atten år gammel forlod han Ribe som malersvend.

I den følgende tid levede han et omskifteligt, nærmest vagabonderende liv, hvor sult, kulde og sygdom var nogle af de fjender, han sloges med. Vendepunktet indtraf $\mathrm{i}$ i 862. Han lagde billet ind på en annonce og fik plads som huslærer for mejeriforpagterens og godsforvalterens børn på Holsteinborg. Lensgreven hjalp ham økonomisk til et fjerdingår i København, hvor han tog skolelærereksamen. Atter fulgte en periode som huslærer samtidig med, at han forberedte sig til examen artium og studerede naturvidenskab, især zoologi og botanik. I 866 fik han Kulturministeriets stipendium til det såkaldte „Monradske Kursus“ på Polyteknisk Læreanstalt. (Dette kursus var forløberen for Danmarks Lærerhøjskole, hvor datidens realskolelærere uddannedes). Her traf han blandt lærerne zoologen J. C. Schiødte, som selv var vokset op i trange kår, og som fattede stor interesse for den unge Hansen. I 869 fuldførte Hansen sin uddannelse dèr, ernærede sig en tid som manuduktør for veterinærer og medicinere og som lærer ved Schneekloths Skole.

I 87 I blev han student, tog filosolikum og kunne endelig begynde studierne ved Københavns Universitet. En overgang bistod han Japetus Steenstrup med dennes mosegeologiske undersøgelser, gjorde et fund, som væltede den etablerede kronologi, men følte sig utryg ved Steenstrup, som han mistænkte for at ville „sætte sig på“ ham og forhindre en offentliggørelse under hans eget navn af fundet; han mente også, at en strid mellem Steenstrup og Schiødte havde afsmittende negativ effekt på ham.

Steenstrup forblev hans yndlingsaversion livet igennem. „Det værste, det utåleligste, og jeg kan tilføje det farligste ved denne gamle skurk er, at han bestandigt fromt lægger hovedet på den ene side og svøber sig ind i mild med kirkelig fernis lakeret godhed. "8) Sådan lød den vrede students dom over professoren i 1875 . En lille menneskealder senere, i I 897, ristede Hansen denne minderune bag på den sortrandede, trykte notits om Steenstrups begravelse: „Han elskede særlig sådanne videnskabelige undersøgelser hvor den skarpe afgørelse ikke rykker forskeren ind på livet, men hvor der bestandig er det store spil af muligheder og sandsynligheder at operere med. Den egentlige eksakte videnskab lå ham åbenbart fjern, $\mathrm{i}$ hvor stor interesse han end havde af videnskabelig forskning i almindelighed. ${ }^{(9)}$ ) 
I anden forbindelse inddelte Hansen naturforskere i to kategorier. Den første var karakteriseret ved at være udstyret med større dristighed end skarpsindighed. „Derfor kunne de udtale halvt gennemtænkte og ofte slet ikke prøvede ideer; de er vækkende, giver mange impulser, men bringer i almindelighed ligeså megen forvirring som virkelig oplysning frem. Den kritikløse mængde vil altid blive bedåret af dem." Den anden gruppe, derimod, lod skarpsindighed tøjle dristigheden. „De beholder det halvt gennemtænkte og ufærdige hos sig selv. De er stolte personligheder uden reklame og deres arbejder er ofte mere intensive end extensive.“ Og han tilføjede: „For mængden står de i reglen i en vis kølig afstand. ${ }^{10}$ ) Dette pyntelige selvportræt blev afleveret under en samtale med J. C. Jacobsen med tydelig adresse til Jacobsens slægtning og videnskabelige rådgiver, medlem af Carlsbergfondets direktion og af laboratoriebestyrelsen, Videnskabernes Selskabs grand old man, den brillante Steenstrup.

Forøvrigt var Emil Chr. Hansen i studietiden optaget af Darwin, hvis Rejse om Jorden han oversatte sammen med Alfred Jørgensen. Den udkom i 1876 på Salmonsens forlag. Samme år fik Hansen universitetets guldmedalje for et arbejde over de danske gødningssvampe. Hermed nærmede han sig det område, der skulle blive hans hovedfelt. Opfordret og vejledet af professor P. L. Panum gik han i lag med gæringsfysiologiske studier, som i 1879 gav ham doktorgraden med afhandlingen $\mathrm{Om}$ Organismer i Øl og Ølurt. Studierne hertil indledtes på Panums institut, og afsluttedes på Carlsberg Laboratorium, hvortil han I. januar 1878 knyttedes $\mathrm{i}$ den stilling, der var blevet ledig ved botanikeren Rasmus Pedersens afgang. Et halvt år tidligere havde Carl Jacobsen iøvrigt på Japetus Steenstrups anbefaling - ansat ham ved Ny Carlsberg Bryggeriets driftslaboratorium, men afstod ham til faderen til forskerstillingen ved det kun to år gamle laboratoriums fysiologiske afdeling.

Der var problemer med at få lov til at disputere. Hansen havde ingen kandidateksamen, og et flertal i Konsistorium ville ikke dispensere. Det gjorde imidlertid ministeriet. Da Emil Chr. Hansen sendte sin doktorafhandling til sin nye chef, J. C. Jacobsen, omtalte han i et ledsagende brev universitetets $\mathrm{i}$ hans øjne uvenlige indstilling. I sit takkebrev forsvarede Jacobsen universitetet: „Det er min overbevisning som med min stigende livserfaring er blevet bestandig stærkere, at intet samfund og ingen institution kan drives, ja næppe nok bestå, dersom man for ofte og for let rokker ved det fundamentale grundlag, hvorpå det er bygget. Jeg tilstår, at man efter min formening ikke har været konservativ nok i den heromhandlede retning." Det er velkendt, at J. C. Jacobsen 
begyndte som nationalliberal og endte som konservativ. Og til disse ord føjede Jacobsen sin bekymring over ,den synlige bitterhed, hvormed den formentlige uret har fyldt Deres sind og det noget for stærke (exalterede) udtryk af selvfølelse og selvtillid, som denne stemning har aflokket Dem (sammenligningen med Pasteur)."

Hansen skyndte sig at forsikre Jacobsen om sin agtelse for Pasteur: „Mit arbejde er ringe i sammenligning med mesterværker som Pasteurs, men jeg tror det betragtet som doktordisputats er godt, og denne opfattelse har jeg endnu. Det vil nærmest kunne sammenlignes med Salomonsens afhandling om blodets forrådnelse." ${ }^{12}$ ) Hermed sigtede Hansen til lægen og bakteriologen Carl Julius Salomonsens studier over blodets forrådnelse, som kom samme år. ${ }^{13}$ ) Iøvrigt kunne han ikke dy sig for at henvise til, at så ansete videnskabsmænd som Julius Thomsen, C. T. Barfoed, Japetus Steenstrup og J. C. Schiødte ingen disputatser havde skrevet; to af dem (Thomsen og Barfoed) havde ingen examen artium, Steenstrup havde kun denne eksamen, men ingen universitetseksamen, og Schiødte var uden eksamener overhovedet. Jacobsen overværede forsvaret af disputatsen, og ifølge Eugen Warming, som var en af opponenterne, gik, ,kaptajnen“ meget op i handlingen. Nu og da gav han sig højlydt til kende fra sin plads i auditoriet, til stor morskab for forsamlingen. ${ }^{14}$ )

Når jeg har bragt denne lille ordveksling frem, er det ikke så meget af kuriøse grunde, men fordi den er symptomatisk for de følgende år, gennembrudsårene fra 1879 til 1884 , hvor Hansens grundlæggende teoretiske og praktiske arbejder bliver til, og hvor Pasteur kommer til at stå som en Molok mellem ham og Jacobsen.

J. C. Jacobsen betragtede sig som empiriker. ${ }^{15}$ ) Han havde lært tilvirkningen af undergæret lagerøl (bajersk øl) i München og overført denne teknik til Danmark i rette øjeblik. I 847 åbnede han sit dertil indrettede, nyopførte bryggeri Carlsberg, opkaldt efter sønnen Carl og den bakke, hvor bryggeriet var blevet placeret, Valby bakke. Det nye produkt faldt omgående i publikums smag, og blandt de hjemlige bryggere placerede han sig som en foregangsmand. Han folte sig overlegen i dygtighed og indsigt, priste sig lykkelig over, at han havde fået så tilpas med kundskaber, at han nogenlunde kunne forstå, hvad det kom an på. Men han forstod også, at verden ikke blev stående stille. Udforskningen af de for ølbrygningen fundamentale processer var i stærk udvikling. I et brev 
til sønnen Carl skrev han i 1855 fra en rejse i udlandet, at han var godt på vej til at blive overfløjet som rationel brygger, ja måske allerede var det, hvis man målte ham med en europæisk alen, og han fortsatte: „Den, der besidder de grundigste kundskaber i kemi og hjælpevidenskaber i forbindelse med den fornødne praktiske færdighed og indsigt, han vil være Europas førende brygger i den kommende generation. " ${ }^{16}$ ) Derfor ville han, at sønnen skulle have en teoretisk uddannelse. Han satte hele sin faderlige autoritet - og den var ikke ringe - ind derpå. Af samme grund oprettede han senere laboratoriet.

Hans erfaring sagde ham, at øllets lagring var nøglen til hans egen succes. Med bekymring så han på en tendens, han nogle steder på sine rejser mente at kunne iagttage, til at levere halvt aflagret bajersk øl. For sit eget vedkommende var han besluttet på uanset markedets efterspørgsel at fastholde den grundige lagring. Lagerkældrene skulle bestemme produktionens størrelse, ikke brygværket og ikke publikum.

Oprindelig var det J. C. Jacobsens plan at skaffe Carl et bryggeri i provinsen, når han havde tilendebragt sin uddannelse. Wibroes Bryggeri i Helsingør var en kort stund i hans tanker. Under alle omstændigheder ville han ikke optage sønnen i forretningen. Deres karakterer var for forskellige til, at han kunne forestille sig, at et sådant samarbejde i den daglige ledelse ville blive vellykket. Ej heller lagde han over for sønnen skjul på, at han ønskede at bevare ledelsen af Carlsberg til sin død. ,Jeg duer ikke til at sysle." Carlsberg var et én-mands foretagende og skulle forblive så. Det var et andet af J. C. Jacobsens principper - ikke ukendt blandt grundlæggere af store virksomheder - at han helst så bryggeriet fastholdt på et niveau, som gjorde det muligt for ham at overskue og lede operationerne. Det større Carlsberg, som Jacobsen opførte efter en brand i 1867 , der lagde det gamle anlæg øde, betragtede han som færdigt og afsluttet. Hans nærmeste medarbejder var E. Kogsbølle, og ham gjorde han året efter til sin kompagnon.

På dette tidspunkt havde Carl Jacobsen opholdt sig i næsten fire år ved en række af Europas førende bryggerier og var færdiguddannet. Faderen besluttede da at bygge et selvstændigt bryggeri til sønnen. Tanken var, at Carl Jacobsen, som bl.a. havde gæstet Wm. Younger's bryggeri i Edinburgh og Evershed's i Burton-on-Trent, i Valby skulle oparbejde en produktion af forædlet overgæret øl af den engelske type, dels til hjemmemarkedet, dels til eksport. Bryggeriet, det såkaldte Annexbryggeri, stod færdig i i 87 I. Carl fik det i leje og begyndte straks sin virksomhed på dette anlæg, som hørte til blandt tidens mest avancerede. Han drev det for egen regning. 
Det viste sig imidlertid hurtigt, at der - bortset fra porter - ingen større interesse var hos publikum for de engelske ølsorter. Efterspørgslen efter lagerøl var derimod langt fra dækket med de eksisterende bryggerier, og Carl Jacobsen gik følgelig allerede samme år i gang med at brygge bajersk øl. Faderen overførte sine provinskunder til sønnen. Overførslen fuldendtes i 1873 . Derefter trak J. C. Jacobsen sig tilbage fra de københavnske forstæder, som han ligeledes overlod til sønnen. Denne salgspolitik afsluttedes 1878 . Alligevel steg kravene til bryggerierne fortsat. J. C. Jacobsen mente, at hans egen produktion, som var blevet udvidet i flere omgange, nu nærmede sig det optimale. Samtidig meldte tvivlen sig med hensyn til sønnens virksomhed, som var blevet mere kommerciel og større, end han havde forestillet sig.

Men også på andre felter følte han, at sønnens og hans veje var ved at skilles. Hvor han havde bryggeridrift som den alt dominerende interesse, forekom det ham, at sønnen, der i disse år ofrede en betragtelig del af sine store indtægter på kunstindkøb, dyrkede andre guder ved siden af. Men især var han af den opfattelse, at sønnen forsømte produktudviklingen, som J. C. Jacobsen fortsat mente var det moderne bryggeris fornemste pligt, idet arbejdet med at beherske processerne langt fra var afsluttet. Han besluttede sig da til at afbryde samarbejdet. I november I 879 foreslog han sønnen, at denne skulle opføre et nyt bryggeri for egne midler nær ved lejebryggeriet og drive det helt på eget ansvar. Bryggeriet indviedes den 14 . august $\mathrm{I} 88 \mathrm{I}$.

J. C. Jacobsen blev væk fra indvielsen, en åben demonstration af det brud mellem fader og søn, som da var en kendsgerning. Bruddet betød, at Jacobsen, for at sikre at hans bryggeri efter hans død ville blive videreført efter hans principper, realiserede tanken om at testamentere det til Carlsbergfondet. I maj måned opsagde han sønnens lejemål af Annexbryggeriet med virkning fra $\mathrm{I}$. oktober $\mathrm{I} 882$ for at lægge det til sit eget og dermed lade også dette indgå i testamentets bestemmelse om overdragelsen til Carlsbergfondet. Denne beslutning kom bag på Carl Jacobsen, som havde planeret sit nybyggeri i tilslutning til Annexbryggeriets brygværk. Han måtte i hast revidere sine tegninger og indrette et nyt værk, således at anlægget blev en afsluttet og selvstændig enhed. Yderligere belastende for forholdet mellem fader og søn var J. C. Jacobsens krav om, at sønnen på sit nye bryggeri afstod fra at benytte navnet Carlsberg. Faderen var besluttet på at bevare sin førende position på lagerølsområdet. Navnet var i den forbindelse vitalt.

Her trak J. C. Jacobsen det korte stră. Sønnen havde, da faderen opsagde lejekontrakten, anmeldt sit nye bryggeri under navnet $\mathrm{Ny}$ 
Carlsberg, og myndighederne anerkendte firmabetegnelsen. Den 17 . januar I 882 blev der underskrevet en overenskomst mellem fader og søn. Faderen ville forene sine to bryggerier under navnet Gamle Carlsberg, sønnen kunne kalde sit bryggeri Ny Carlsberg, men skulle sørge for at undgå forveksling af navnene. Endvidere fik sønnen tillagt en trediedel af J. C. Jacobsens formue som fædrenearv - ca. I mill. kr. mod at give afkald for sig og sin descendens på arv efter faderen. På disse vilkår forpligtede sønnen sig til at påtegne sit samtykke på faderens testamente.

Testamentet blev oprettet den 20. februar i 882. Carlsbergfondet fik herved skænket de to forenede bryggerier, om hvis drift det $\mathrm{i}$ fondets fundats hed, at „det skal være det stadige formål uden hensyn til en øjeblikkelig fordel at udvikle fabrikationen til den størst mulige fuldkommenhed, således at disse bryggerier og deres produkt altid kunne stå som et mønster, og ved deres eksempel virke til at ølbrygningen her $\mathrm{i}$ landet holdes på et højt og hæderligt standpunkt. ${ }^{\text {(17) }}$ ) Dette skulle ske ved et nært saııarbejde med laboratoriet og under ledelse af en med fornøden selvstændighed stillet driftsbestyrer.

Dramaet mellem fader og søn rullede imidlertid videre og udspillede sig snart på åben scene, først i den Valby'ske lilleverden, siden for et voksende eksternt publikum. Under et langt aftenbesøg $\mathrm{i}$ foråret $\mathrm{i}$ laboratoriet beklagede J. C. Jacobsen sig til Emil Chr. Hansen over sønnens forcerede bryggeridrift. „Der var her et suk, og jeg følte medlidenhed med den gamle mand," hedder det i Hansens optegnelse om samtalen. ${ }^{18}$ ) Hansen vidste, at Carl samme dag havde sendt nogle af sine folk over til faderens bolig med to læs bohave, malerier, bøger m.v., altsammen foræringer, han $\mathrm{i}$ årenes løb havde modtaget, men nu ikke længere ville beholde. Folkene havde besked om at læsse godset af $i$ forstuen, og hvis de ikke fik lov dertil, da at lægge det hele udenfor på græsplænen, eventuelt hurtigt spænde hestene fra vognene og lade disse stå. „Min fader kan da også beholde dem med.“ „Kaptajnen“ (J. C. Jacobsen var kaptajn i borgervæbningen og yndede denne titel) var dog ikke hjemme, og alt var roligt blevet afleveret.

For yderligere at tydeliggøre bruddet lod sønnen porten mellem $\mathrm{Ny}$ og Gamle Carlsberg afspærre således, at forældrene ikke kunne køre ad den gamle rute til og fra byen. Også vejen langs de to bryggerier blev et stridsemne. Sønnen kaldte den for Pasteurs Vej, medens faderen ønskede navnet Alliance Vej. „De to forrykte mennesker slår hver for sig det ene skilt op dernede større end det andet," bemærkede Hansen, „idet den ene søger at dække den andens vejnavn. De blir derved til spot 
endog for arbejderne og skandalen er gået over i flere aviser, således også i provinsbladene. "19)

Hansen havde egentlig forståelse for sønnens situation, men modstod Carls i sommerens løb gentagne tilbud om at skifte arbejdssted og få stillet et stort forskningslaboratorium til rådighed på $\mathrm{Ny}$ Carlsberg samt bedre gage og ordnede pensionsforhold. ${ }^{20}$ ) Trods mange irritationspunkter anså han Jacobsen senior for at være en ejendommeligt begavet mand, hvis interesse for virksomheden og for videnskaben skilte ham fra andre og aftvang respekt. „Han tager bryggerierne på mere ideel måde end nogen anden brygger, jeg kender." ${ }^{21}$ ) Når noget skulle fremmes, ofrede han rundeligt, hvad enten det drejede sig om bryggeriet, Carlsbergfondet eller Frederiksborgmuseet (oprettet af Jacobsen 1878 som en særlig afdeling af fondet). „Hans fortjeneste og store fortjeneste bliver da væsentlig den, at han ikke har brugt sine penge til et overdådigt fornemt liv, men anvendte dem til åndelige interessers fremme."

Bagsiden af medaljen var brygger Jacobsens uro og lunefulde væsen. „Kaptajnen har ikke hvile i noget, der bygges og tumles uafbrudt, sønog helligdage kender han ikke. Han driver på, en uhyre virksomhed udfolder han, men springende og i reglen mere eller mindre planløst. "22) Omgivet af „en sværm af beundrere og ærbødige smårøvere“ var det efter Hansens vurdering svært for den 7o-årige brygger at få et godt råd fra nogen. ${ }^{23}$ ) Meget arbejde gik til spilde. „En administration [...] hvor hver har sit område at passe med bestemt myndighed og tilsvarende ansvar, kendes ikke her. Det samme lider vi under på laboratoriet. Også her vil han skalte og valte efter sit lune. Han lider ikke, at Kjeldahl og jeg virkelig træder op som forstandere." ${ }^{24}$ )

Således så sagen ud fra de Hansen'ske vindver i 1882 . Målt med historiens alen må man dog sige, at J. C. Jacobsens indsats i løbet af I880'erne var præget af både målbevidsthed og handlekraft. Besjælet af ønsket om for enhver pris at bevare sin førende position på markedet startede han en offensiv, der hurtigt gav resultater. Den gamle mand rystede bestemt ikke på hånden. Hans modstandere fandt ham hensynsløs. Det forhindrede dem nu ikke $\mathrm{i}$ at søge hans råd og bistand $\mathrm{i}$ bryggeritekniske anliggender $\mathrm{i}$ en vanskelig situation. Og de fik hans hjælp, hvilket er paradoksalt, men logisk nok, når man betænker hans store ærgerrighed: at være et mønster for sin stand og dens førstemand. 


\section{VII}

I denne atmosfære af krig på kniven var opstandelsen stor, da øllet i gærkælderen på Gamle Carlsberg i efteråret $\mathrm{r} 88_{3}$ begyndte at antage en ubehagelig, bitter smag og fik en ilde lugt. Nok kendte man fra tidligere til udsving i øllets kvalitet, men disse havde som regel været kortvarige og uden markedsmæssige konsekvenser. Med rette fremhævede Jacobsen som noget unikt, at han på sit bryggeri ikke havde skiftet gær, siden han i 1845 havde skaffet sin påsætgær fra Gabriel Sedelmayers bryggeri i München. Jacobsen gik selv i gang med undersøgelser. Fra laboratoriet rekvirerede han - til Hansens irritation - det store engelske mikroskop og spejdede i uger efter bakterier, uden andet resultat end et ødelagt objektiv. ${ }^{25}$ ) Den forringede holdbarhed af øllet, som også konstateredes, foruroligede ham i den grad, at han gav sin direktør, Kühle, som var på rejse i udlandet, besked om at skaffe ny gær fra München. ${ }^{26}$ ) Den 7 . september skrev Jacobsen til Kühle: "Dr. Hansen har undersøgt bundfaldet i flaskeøllet mikroskopisk og fundet, at det indeholdt vild gær, hvilket han nu begynder at undersøge ved ascosporedannelsesmetoden. Dr. Hansen vil forsøge at udskille ren (saccharomyces) cerevisiae af vor egen nuværende gær, hvilket vil blive meget interessant, men det vil tage så lang tid, før han kan producere tilstrækkeligt til påsæt, at jeg ikke tør udsætte anskaffelsen af gær derefter. ${ }^{\text {"27) }}$ ) Otte dage senere rapporterede han i forlængelse heraf: „Kan det lykkes Hansen af den med vilde gærformer forurenede gær - forureningen er nu utvivlsom - at udskille sacc. cerevisiae i tilstrækkelig mængde til praktisk brug, vil det være til stor ære for laboratoriet og af stor betydning for bryggerierne. ${ }^{\text {"28 }}$ )

Det lykkedes. Den I2. november anvendte man for første gang rendyrket gær ved brygningen af øl på Gamle Carlsberg. Allerede året efter var bryggeriets totale produktion på $200.000 \mathrm{hl} ø \mathrm{l}$ baseret på rene stammer af gær. Det samme gjaldt for det næsten lige så store kvantum øl, der fremstilledes på nabobryggeriet, Ny Carlsberg. Som en løbeild sprang den ny metode fra bryggerierne i Valby til de øvrige bryggerier inden og uden for landets grænser. Få år senere var anvendelsen af rene gærstammer den normale procedure ved fremstillingen af undergæret $ø l$ på alle større bryggerier verden over.

J. C. Jacobsen, som i september 1882 netop var vendt hjem fra en udenlandsrejse, fortalte på et af sine aftenbesøg i laboratoriet hos Emil Chr. Hansen, at tyske kolleger havde rost Hansens undersøgelser (offentliggjort i Carlsberg Laboratoriets Meddelelser, I. bd., 4. hefte) og bedt om at måtte blive holdt løbende underrettet om gærstudierne. 


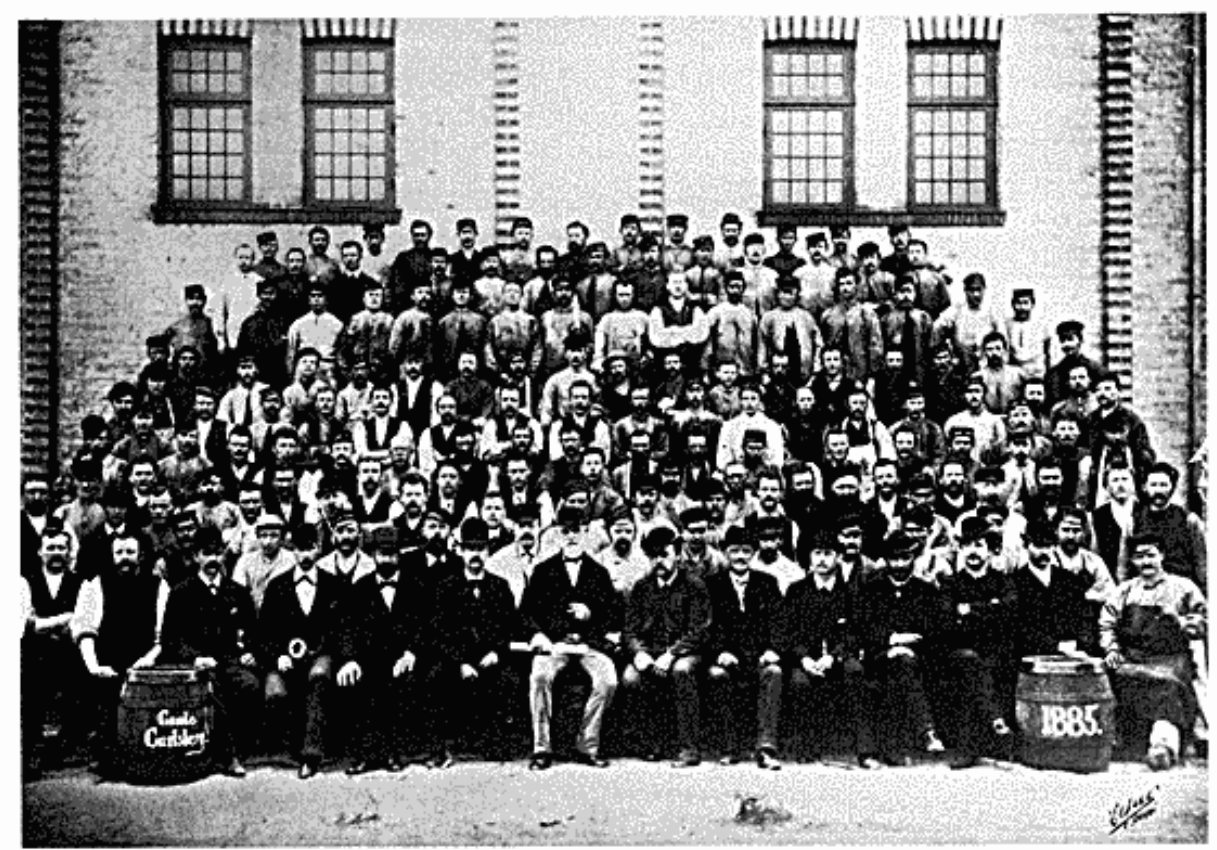

J. C. Jacobsen fotograferet sammen med bryggeriets arbejdere og funktionærer i $188_{5}$. Carlsberg Museum.

„Han opfordrede mig indtrængende til, såsnart mine undersøgelser tillod det, at udgive en række populære skrifter på tysk med talrige illustrationer og $\mathrm{i}$ det hele affattede $\mathrm{i}$ en tilgængelig form, og heri meddele det væsentlige af mine i Carlsberg hefterne publicerede undersøgelser, for at de kunne blive den store bryggerverden tilgængelig," hedder det $\mathrm{i}$ et erindringsnotat fra Hansens hånd om samtalen. ${ }^{29}$ )

I denne fase, den tekniske informationsfase, tørnede de to hovedpersoner sammen. Bryggeren, hvis position blandt europæiske kolleger var nestorens, havde sin mening om, hvordan sagen skulle præsenteres. Her var han fagmanden. Derudover var han grundlægger og ejer. Det var hans øl og hans gær, det drejede sig om. Han ønskede at introducere nyheden, hvilket ikke betød, at han prøvede på at udelade Emil Chr. Hansens navn fra reformen. Alvorligere var det, at Jacobsen ikke tillod, at man rokkede ved Pasteur's autoritet. Hansens teori skulle afstemmes efter og indplaceres i Pasteur's lære. Man kan også sige det på den måde, at J. C. Jacobsen egentlig aldrig begreb teorien bag Hansens reform. Resultatet blev et sammenstød mellem to hver for sig meget principfaste og viljestærke personligheder. Der føg gnister.

Hansen var overkørt efter en meget intensiv arbejdsindsats, hvor han 
ud over gærstudierne havde făet andre opgaver pålagt. På Jacobsens foranledning måtte han således give sig $\mathrm{i}$ kast med en analyse af det københavnske drikkevand, som var inficeret med alger. Professor Panum sendte smørløbefabrikant Chr. Hansen (grundlæggeren af Chr. Hansens Laboratorium) til konsultation hos navnefællen og bad endvidere om, at en docent fra Lund måtte få et kursus i bakteriologi. Emil Chr. Hansen blev bitter på J. C. Jacobsen og tilgav ham aldrig. Også på et andet punkt skuffede ,kaptajnen“ ham. Jacobsen afslog blankt at etablere en gæranstalt, fra hvilken salg af ren gær kunne ske. Det sårede Hansen, at den rige brygger afviste forslaget om at markedsføre reformen. Det ærgrede ham, at andre realiserede tanken (f.eks. Alfred Jørgensens gæringsfyiologiske Laboratorium herhjemme og Heineken's gæranstalt i Holland). Tilmed drejede det sig om folk, som Hansen efter Jacobsens og laboratoriebestyrelsens anmodning havde uddannet på de gærfysiologiske kurser, der hurtigt etableredes med deltagere fra nær og fjern. Endelig syntes han, at det var nærigt af Jacobsen ikke at give ham et gagepålæg i betragtning af den store økonomiske fordel, bryggeriet nød af hans gærreform. Sammenlignede han sin egen løn med den administrerende direktørs, fandt han, at der var tale om et helt urimeligt misforhold.

Striden kulminerede i forsommeren $\mathrm{I} 884 \mathrm{\cdot}^{30}$ ) Efter opfordring fra professor Julius Thausing havde Hansen skrevet en af Jacobsen gennemlæst og -rettet artikel til det østrigske Allgemeine Zeitschrift für Brauerei. Artiklen blev med tak modtaget af redaktionen og sendt til trykkeriet. Men Jacobsen, som ikke var ganske tilfreds med præsentationen, tvang under et besøg i Wien redaktør Fassbender til at sende manuskriptet retur til København med besked om, at det ikke kunne offentliggøres. Ikke nok hermed. I Wien skrev Jacobsen sin egen version, som bragtes i et særnummer, tidsskriftets redaktion havde tilrettelagt til en forestående tysk bryggerkongres i Berlin. Hansens modtræk betod $\mathrm{i}$ at sende den refuserede afhandling til professor Lindtners hæderkronede tidsskrift Zeitschrift für das gesammte Brauerwesen, München, som straks publicerede den.

Ved Jacobsens tilbagekomst til København sendte Hansen ham et brev, i hvilket han skrev: ,Jeg er inderlig bedrøvet over, at De har kunnet tilføje mig denne uret og denne min sorg bliver større derved, at der i Deres bearbejdelse har sneget sig rent faktiske fejl ind. Jeg tænker her slet ikke på spørgsmålet om Pasteur's betydning, men kun på, hvad jeg virkelig har meddelt i mit arbejde og hvad der ikke meddeles deri.“ ,Jeg er kommet ud over ungdomsårene, hvert øjeblik er kostbart og 
uforsvarligt at spilde i unødvendig strid, derfor beder jeg Dem om fred og for at få denne vil jeg gøre Dem alle de indrømmelser, som min samvittighed og min ære som videnskabsmand tilsteder." ${ }^{\text {"31 }) ~ B r e v e t ~}$ mundede ud i ønsket om forbedrede vilkår i arbejdet på fysiologisk afdeling, hvilket Jacobsen indvilgede $\mathrm{i}$ med ordene: ,Jeg tror, at hensynet til laboratoriet kræver, at al videre diskussion om zeitschriftartiklen, som nu er et fait accompli, herved bør være afsluttet. “32)

\section{VIII}

Den endelige og afgørende anerkendelse lod dog ikke vente længe på sig. Fjorten dage senere dukkede husguden op i København. Pasteur i egen person kom $\mathrm{i}$ begyndelsen af august måned til byen til den internationale lægekongres ${ }^{33}$ ) og aflagde $\mathrm{i}$ forbindelse hermed besøg på Gamle Carlsberg og Carlsberg Laboratorium. Og dermed var kampenes år på den hjemlige arena ved at være forbi for Emil Chr. Hansen. Lad mig slutte med en reportage fra denne celebre begivenhed, således som Hansen oplevede og nedfældede den i sin dagbog:

Det var en lørdag formiddag, at jeg første gang mødte Pasteur. Om formiddagen havde de berømte englændere Paget og Archland været på laboratoriet, de gjorde et særdeles behageligt indtryk. I Pasteurs høflighed var der gennemgående noget koldt.

Kaptajn Jacobsen kom gående med ham nede fra hovedbygningen, og vi hilste på hinanden uden for laboratoriet. Medens alle vi andre, da vi kom ind i dette, tog vore hatte af, også den gamle kaptajn, som forresten ellers plejer at beholde sin hat på, satte Pasteur sig ganske ugenert ned med den høje sorte hat på hovedet.

Jeg beklagede for ham, at jeg ikke kunne tale fransk og bad ham om tilladelse til at tale enten engelsk eller tysk. Hertil svarede han, at han ikke forstod andet sprog end fransk. Da han taler langsomt og tydeligt, er det forholdsvis let at forstå ham.

Vor samtale drejede sig om mine nye gærundersøgelser, og han gik da nærmest ind på at påvise, hvorledes de efter hans mening dels udsprang fra hans egne arbejder og dels fra hans disciple f.eks. Gajon. Da jeg bragte spørgsmålet frem, hvorvidt Pasteur ved sine dyrkningsforsøg med patogene bakterier havde fremkaldt foreløbige eller konstante fysiologiske ændringer, søgte han at hævde, at der virkelig var dannet nye fysiologiske varieteter, men han kom herved i modsigelse, og jeg fik indtryk af, at den dybere teoretiske betydning af dette sprøgsmål lå ham fjernt. Pasteurs undersøgelser standser jo som regel der, hvor deres 
praktiske interesse hører op. Han indbød mig til at besøge sig i Arbois og i Paris og opfordrede mig til at studere de patogene mikroorganismer. Vi skiltes lidt køligt.

Næste dag, søndag eftermiddag, kom flere af de franske læger på laboratoriet. Pasteur stod i Kjeldahls dør ud til entreen, til begge sider af ham havde Kjeldahl, de fornævnte og jeg grupperet os. Det var navnlig til dr. Bourquoy, at Pasteur henvendte ordet.

Alle stod med blottede hoveder og lyttede opmærksomt og ærbødigt, kun Pasteur havde beholdt sin høje, sorte hat på. En stor stjerne funklede på hans bryst, og den lille mand knejsede og talte med megen energi. Han holdt foredrag over over- og undergæring og flettede deri en kompliment til mig ind.

Da klokken var blevet 6 , gik vi til kaptajnen, hvor der blev givet en meget fin middag. Verneuil sad ved siden af kaptajn Jacobsen. Pasteur lige overfor. Madvig præsiderede for enden af bordet med gamle fru Pasteur. Kaptajn Jacobsen holdt en temmelig svulstig tale til ære for Pasteur. Denne takkede ved at yde Jacobsen en lige så stor ros og omtalte også med anerkendelse det fremskridt, jeg havde bragt gæringsindustrien. Dr. Hornemann, som var til stede, henviste senere dertil i sit Hygiejnisk Tidsskrift.

Ved afskeden denne aften og nogle dage senere på banegården ved afrejsen indbød han mig atter til at besøge sig i Paris. Han viste sig således efterhånden fra en venligere side. Under sit ophold $\mathrm{i}$ København blev han formelig forgudet og tyskerne blev under hele kongressen skudt til side. Koch og flere andre fremragende tyske forskere mødte derfor ejheller. ${ }^{34}$ )

Emil Chr. Hansen tog imod Pasteur's indbydelse og rejste $\mathrm{i}$ foråret $1885^{35}$ ) til Paris. Gallisk esprit lå ham fjernt, han var gotisk, uden stor sans for det romanske, men endte dog med at tabe sit hjerte til den franske hovedstad.

Pasteur viste ham elskværdig opmærksomhed, ledsagede personlig Hansen rundt $\mathrm{i}$ laboratorierne $\mathrm{i}$ Paris og modtog ham på forsøgsstationen uden for byen, hvor arbejdet med hundegalskaben, som i disse år var i centrum for Pasteur's forskning, foregik. Hans virkefelt var som bekendt overordentlig vidtspændende, og han havde på dette tidspunkt forlængst lagt den industrielle microbiologi bag sig.

En særlig oplevelse beredte Pasteur den danske forsker ved at invitere ham til indtrædelsesfesten for Ferdinand vicomte de Lesseps i det navnkundige franske akademi. Ceremonien bød på en overfyldt forsam- 


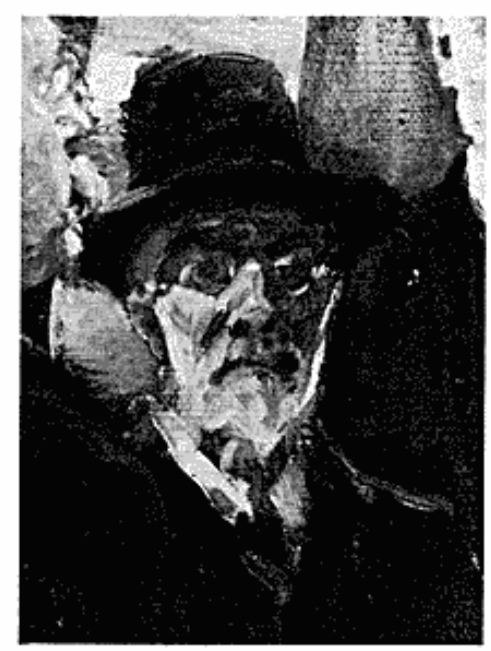

Emil Chr. Hansen i et udsnit af P. S. Krøyers maleri Industriens Mand fra 1903-04. Frederiksborgmuseet. Foto: Lennart Larsen.

ling af festklædte damer og herrer, blomsten af Frankrigs berømtheder. Festens genstand, Suez-kanalens skaber, blev ledsaget af gamle Victor Hugo. Efter at Lesseps havde oplæst sin indtrædelsestale, svarede Ernest Renan med et spirituelt foredrag. Den altid skarpt iagttagende Hansen, for hvem ingen detaille var for ubetydelig, end ikke i en festlig stund, noterer i sin dagbog, at damerne var stærkt sminkede, og tilføjer: „Det har også været påfaldende for mig at se hvor almindelig det er i Paris at finde kvinder med endog temmelig stærkt udviklet skæg, især overskæg. " ${ }^{36}$ )

To gange blev Hansen inviteret til middag en famille hos Pasteurs. Konversationen var livlig, ,der blev pludret meget ved bordet, " bagefter blev der musiceret og sunget, lystigheden var stor, men det kneb for Hansen at følge med de mundrappe franskmænd, og deres arrogance irriterede ham. Blandt selskabsreplikkerne mente han at opfange Pasteur's karakteristik af dansken: „Et stille, alvorligt folk, de forstår ikke spøg og har altid hovedpine. ${ }^{(37}$ ) Det må i sandhed siges at være en karakteristik, som den danske gæst levede op til. Hansen formelig plagede sin vært med sine hjemlige bekymringer. Han underholdt ham indgående om utilfredsstillende ansættelsesvilkår og om det anspændte forhold til bryggeren. Louis Pasteur tilskyndede imidlertid af al kraft Hansen til at beholde stillingen på Carlsberg Laboratoriet. I et brev forud for besøget skrev han herom: ,Je vous estime beaucoup et j'ai d'autrepart une sorte de culte pour les grandes qualités de M. Jacob- 
sen." ${ }^{\text {"38) }}$ Disse ord levede Pasteur smukt op til, for Hansens vedkommende, da han foranledigede, at guldmedaljen fra La Societé d'Encouragement pour l'Industrie nationale i 1886 blev tildelt den danske forsker. Denne hæder vakte megen opmærksomhed internationalt og indledte den lange række af æresbevisninger, som med tiden blev Emil Chr. Hansen til del.

\section{IX}

Efteråret $\mathrm{I} 88_{4}$ holdt $\mathrm{J}$. C. Jacobsen et foredrag i Den tekniske Forening i København. Det hed „Bryggeriindustriens Fremskridt i de sidste 50 Aar," og man kan kalde det for hans testamente som industrimand og brygger. ${ }^{39}$ ) En fransk version af foredraget forærede Jacobsen til Pasteur under dennes besøg på Carlsberg. ${ }^{40}$ ) Heri nævnte han Emil Chr. Hansens indsats i anerkendende vendinger. Det lunede. Tonen mellem de to kombattanter blev mildere. I marts 1885 talte de om planerne for en ny laboratoriebygning, hvor Emil Chr. Hansen havde leveret et udkast til den fysiologiske afdeling. „Han næsten opfordrede mig til at udvide mine fordringer, “ hedder det i dagbogen, ,og viste mig overhovedet megen hensyn og stor imødekommenhed. Ved sådanne lejligheder er der noget elskværdigt, godmodigt over den gamle mand. Skade at det ikke altid har været tilfældet. " $\left.{ }^{41}\right)$ J. C. Jacobsen døde i Rom den 30 . april I 887 efter at være blevet forsonet med sønnen i løbet af det forudgående efterår.

I r 90 I gjorde Hansen sin gerning op i en populær artikel i tidsskriftet Frem med de ord, som passende kan stå som et epitafium over hans stræben, og hvori Pasteurs navn karakteristisk nok er indflettet:

Teoretiske og praktiske strømme går sammen i mine arbejder, og de giver lige så vel et bidrag til gæringsteknikken og gæringskemien som til bakteriologien. Da deres mål er at bringe reformer frem, måtte de $\mathrm{i}$ lange tider komme til at stå $\mathrm{i}$ kampenes tegn, men de har tillige bragt mig den forskerglæde, hvorom Pasteur siger: - „Der er intet, der opfylder forskeren mere end det at gøre nye opdagelser; dobbelt stor bliver dog hans glæde, når han ser, at de finder direkte anvendelse i det praktiske liv. ${ }^{42}$ ) 


\section{NOTER}

Henvisninger til Geringsfysiologen Emil Chr. Hansens efterladte breve og optegnelser i Det kgl. Biblioteks håndskriftsamling anføres med katalogsignaturen $\mathrm{NkS}_{4} \mathrm{o69}, 4^{\circ}$. Henvisninger til ECH's dagbøger og papirer i Carlsbergfondets arkiv anføres med forkortelsen ECH dagb. og ECH papirer. - De bragte citater er gengivet i moderne retskrivning.

(1) Kristof Glamann: The scientific brewer: founders and successors during the rise of the modern brewing industry, i: Enterprise and history. Essays in honour of Charles Wilson, ed. by D. C. Coleman and Peter Mathias (Cambridge 1984) s. 186ff. (2) Samme: Bryggeriets historie $\mathrm{i}$ Danmark indtil slutningen af det $\mathrm{r} 9$. århundrede (Kbh. I962) s. 204 ff. Endvidere Hubert A. Lechevalis and Morris Solotorovsky: Three Centuries of Microbiology (New York 1965) s. $38 \mathrm{ff}$. (3) Citeret efter Dieter von Wettstein i Carlsbergfondets årsskrift $\mathrm{I}_{98} 8$, s. 75 ff.; se også sammes A Century Brewing with Yeast Clones (Copenhagen 1983) passim. - (4) ECH dagb., hft. 2, marginalnote. (5) The Carlsberg Laboratory $1876 / 1976$, ed. by H. Holter and K. Max Møller (Kbh. 1976) passim. - (6) Om ECH se Albert Klöcker: Emil Chr. Hansen. Hans Liv og Virksomhed (Meddelelser fra Carlsberg Laboratoriet, 9. rk., 2. hft., I9I 1); endvidere Robert Djurtoft (Carl Christensen) i Dansk biografisk leksikon, bd. 5 (1980), og Kristof Glamann: Emil Chr. Hansen. En forsker i industriens tjeneste (privattryk 1984). (7) Udat. koncept til G. A. Hagemann i anl. af dennes opfordring til ECH om at lade sig portrattere til det hos P. S. Krøyer bestilte billede af industriens mænd. NkS $4^{\circ 6} 9,4^{\circ}$. - (8) 8.4.1875. ECH dagb., hft. I. - (9) Forskell. Papirer til min Livshistorie, 20.6.1897. ECH papirer. Fragment F. - (10) Optegnelser om Kapt. Brygger J. C. Jacobsen, 1 2.5.1882. ECH dagb., hft. 2. - (11) JCJ til ECH, 21.2.1879. NkS 4069, $4^{\circ}$.(12) Sst., ECH's svar i koncept, 22.2.1879. - (13) Hans Lautrop: Carl Julius Salomonsen og bakteriologiens begyndelse i Danmark. Fra Carl Julius Salomonsens arkiv, i: Bibliotek for lager, 12.10.1983, s. $97 \mathrm{ff}$ - (14) Signe Prytz: Warming. Botaniker og rejsende (Kbh. 1984) s. 57. - (15) Kristof Glamann: Carlsbergfondet (Kbh. 1976) s. 39 ff. Om JCJ se iøvrigt Birgit Nüchel Thomsen i Dansk biografisk leksikon, bd. 7 ( $19^{8} \mathrm{I}$ ) , og Torben Holck Colding: J. C. og Carl Jacobsen, i: Familien Jacobsen, af Hans H. Worsøe og Torben Holck Colding (Kbh. 1985) s. 5-16. - (16) Johannes Steenstrup: Carl Jacobsen og hans Fader. En Skildring af to danske Borgeres Udvikling. Efter Breve og Erindring (Kbh. 1921) s. $4^{8 .-(17) ~ T i l l a g ~ t i l ~ F u n d a t s ~ f o r ~ C a r l s b e r g ~ F o n d e t ~ a f ~} 25^{\text {de }}$ September $1876, \S_{4} .-(18)$ Optegnelser om JCJ. ECH dagb., hft. 2. - (19) Sst., s. 147 og I49. - (20) Sst., 12.6.1882. - (21) Optegnelser om JCJ. ECG dagb., hft. 2. (22) Sst. - (23) Sst. - (24) Sst. - (25) Sst., 29.6.1884. - (26) A. Fraenkel: Gamle Carlsberg. Et Bidrag til dansk Industrihistorie og industriel Udviklingshistorie (Kbh. 1897). Heri afsnittet om ren gær s. 229 ff., som i det væsentlige baserer sig på ECH. (27) Sst. - (28) Sst. - (29) Manuskripter og optegnelser. Erindringsbog dat. 7.9.1882. $\mathrm{NkS}_{4} 069,4^{\circ}$. - (30) Materiale til dagb., læg G: Papirer og Breve vedr. min Afhand. „Untersuchungen aus der Praxis der Gährungsindustrie“ $\mathrm{og}$ de i den Anledn. opstaaede Stridigheder med Kapt. J. C. Jacobsen Sommeren I884. Lægget er af ECH påtegnet: 
Brandes. Maa ikke udgives. Det danske manuskript rummer JCJ's blyantsnoter i margin og viser iøvrigt, at ECH ingenlunde afviste alle JCJ's rettelser, jf. s. 6.: „Denne og folgende indvendiger er i det hele fra bryggerens standpunkt berettigede." (31) ECH dagb., hft. 2., s. 155 ff. - (32) JCJ til ECH, 24.7.1884. NkS 4069 , $4^{\circ}$. (33) Ejvind Bastholm: Den 8. internationale lægevidenskabelige kongres i København $188_{4}$, i: Bibliotek for lager, I 5.10 .1984 , s. 288 ff. - (34) ECH dagb., hft. 2-3, s. I6 I ff. (35) Sst., rejsen tiltrædes 3.4.1885. - (36) Sst. - (37) Sst. - (38) Louis Pasteur til ECH, 20.3.1885. NkS $4069,4^{\circ}$ - (39) Den tekniske Forenings Tidsskrift ${ }_{1} 88_{4}$. (40) Pasteur-arkiverne i Bibliothèque Nationale, Paris. Jeg takker bibliotekar Else Delaunay for bistand ved fremskaffelsen af materiale fra Pasteur-arkiverne. (41) 7.3.1885. ECH dagb., hft. 3. - (42) Frem, 21.2.1901, s. I4I. 